Muséologies

Les cahiers d'études supérieures

muséologies

\title{
"Is it conceivable to decolonize the collections from Western museums of modern and contemporary art?" Theoretical and practical aspects
}

\section{Marie-Laure Allain Bonilla}

Volume 8, numéro 2, 2016

Les nouveaux paradigmes

URI : https://id.erudit.org/iderudit/1050761ar

DOI : https://doi.org/10.7202/1050761ar

Aller au sommaire du numéro

Éditeur(s)

Association Québécoise de Promotion des Recherches Étudiantes en

Muséologie (AQPREM)

ISSN

1718-5181 (imprimé)

1929-7815 (numérique)

Découvrir la revue

Citer cet article

Allain Bonilla, M.-L. (2016). "Is it conceivable to decolonize the collections from Western museums of modern and contemporary art?" Theoretical and

practical aspects. Muséologies, 8(2), 79-91. https://doi.org/10.7202/1050761ar

Tous droits réservés (C) Association Québécoise de Promotion des Recherches Étudiantes en Muséologie (AQPREM), 2018
Ce document est protégé par la loi sur le droit d'auteur. L'utilisation des services d'Érudit (y compris la reproduction) est assujettie à sa politique d'utilisation que vous pouvez consulter en ligne.

https://apropos.erudit.org/fr/usagers/politique-dutilisation/ 
Article un

"Is it conceivable to decolonize the collections from Western museums of modern and contemporary art?" Theoretical and practical aspects.

Marie-Laure Allain Bonilla 
Marie-Laure Allain Bonilla holds a curatorial studies degree and a doctorate in the history of contemporary art. She is a postdoctoral fellow at the University of Basel where she researches Museum Acquisition Policies in the Age of Globalization, and the possibilities of decolonizing institutional practices. She has been working on establishing a monography on the Johannesburg Biennale in collaboration with Natasha Becker, and has also contributed to published collective works, notably the Carnets du BAL, The Art Even, Qalqalah, Africultures, and Criticism of Art. She is currently working on the publication of her doctoral thesis and the proceedings of the Feminist Subjectivities Conference, Queer and Postcolonial Contemporary Art: a Story in Movements, which she co-organized at the Université de Rennes 2 in April 2015. 
This article departs from an apparently naïve question, "Is it conceivable to decolonize the collections from Western museums of modern and contemporary art?" which is in fact grounded on observations from tangible changes of paradigms in the museum field. These observations focus on some of the largest Western museums' collections, chosen because they are located in former colonial European countries (the Tate Modern London, the Stedelijk Museum Amsterdam, the Musée national d'art moderne in Paris), and/or because they have launched programs that are substantially changing the way their collections are built (the Tate Modern, the Stedelijk Museum Amsterdam and the Guggenheim Foundation). What follows is a preliminary analysis in the framework of a new ongoing academic research which looks at cultural cooperation and decolonizing policies in the West and in formerly colonized countries.

Decolonial thinking has emerged from the work of scholars from South America (Anibal Quíjano, María Lugones, Walter Mignolo, Ramón Grosfoguel) who are attempting to stray from the Western canon of thought and to produce a radical alternative knowledge which takes "seriously the epistemic perspective/cosmologies/insights of critical thinkers from the Global South thinking from and with subalternized racial/ethnic/sexual spaces and bodies." 1 This is not an anti-European critique, "it is a perspective that is both critical of Eurocentric and Third World fundamentalisms, colonialism and nationalism." ${ }^{2}$ In the context of museums, to decolonize would mean "both resisting the reproduction of colonial taxonomies, while simultaneously vindicating radical multiplicity." 3 It would start out by recasting modernism, insofar as this paradigm

1 GROSFOGUEL, Ramón. "The Epistemic Decolonial Turn." Cultural Studies, vol. 21, no. 2-3, March/May 2007, p. 212.

2 Ibid.

3 “Introduction." In L'Internationale Online (Ed.). Decolonising Museums. 2015, p. 5: http://www.internationaleonline.org/bookshelves/decolonising_museums, Retrieved January 2016 is intrinsically bound with European imperialism and coterminous with Eurocentrism. According to decolonial thinking, museums will not be able to decolonize their practices if they stick to the old taxonomies and values of art history as it was built. If we follow Dipesh Chakrabarty's prescription for the discipline of history, Europe should be provincialized and a transcultural approach of art history is much needed. ${ }^{4}$ As Monica Juneja wrote:
"Recasting modernism as a global process involves going beyond an 'inclusive' move to question the foundations upon which the notion of modern has been constructed and to undermine the narrative that hinges upon a dichotomy between the West and the non-West and makes the latter as necessarily derivative, or views it as a series of distant, 'alternative' modernisms." 5

This epistemic turn can be seen in the programming of solo shows from non-Western artists or of temporary historical survey exhibitions that try to recast modernism by adopting a transcultural approach, such as Seven Stories About Modern Art in Africa (1995), Afro Modern: Journeys Through the Black Atlantic (2010), Non-Aligned Modernity: EasternEuropean Art and Archives (2016) or Postwar: Art Between the Pacific and the Atlantic 19451965 (2017), to name just a few. But ideally, a reconfiguration of art history narratives should also lead to a reworking of museums' collections and their display in order to have a more long-lasting effect than a temporary event produces. Even if for Frantz Fanon a tabula rasa theoretically "characterizes at the outset all decolonization," ${ }^{\circ}$ it is hardly an option in the case of a pre-existing collection. Things have to be negotiated within a pre-existing

4 CHAKRABARTY, Dipesh. Provincializing Europe: Postcolonial Thought and Historical Difference. Princeton (NJ): Princeton University Press, 2000.

5 JUNEJA, Monica. "Global Art History and the 'Burden of Representation” Global Studies. Mapping Contemporary Art and Cultures, (BELTING, Hans, BIRKEN, Jacob, BUDDENSIEG, Andrea, WEIBEL, Peter eds), Karlsruhe: ZKM, Ostfildern: Hatje Cantz, 2011, p. 282.

6 FANON, Frantz. "Concerning Violence", The Wretched of the Earth, (trans. Constance Farrington), New York: Grove Press, 1963, p. 35. 
framework. ${ }^{7}$ For example, as has been done at the Weltkulturen Museum in Frankfurt, this negotiation with the collection can be made by inviting scholars and artists to work directly on the objects of the collection in order to create a new comprehension of it, "using small in-roads rather than mainlines within existing anthropological discourse." 8 But even if this experimental methodology, which took place in an ethnographic museum, "can be applied to other museums with varied historical collections," ${ }^{9}$ it is not a sufficient prescription for museums of modern and contemporary art since their collections of art from the 20th and 21 st centuries continuously evolve and grow. To decolonize museums' collections would also means to adopt moral and ethical positions regarding the way artworks are acquired in order to make "museums moral again." 10

To achieve this goal, museums are confronted by two complementary aspects: the theoretical, which can help to give some guidance in solving the epistemological and ethical problems, and the practical. This article will explore, successively, the shortcomings of these two aspects in order to highlight the difficulties museums are facing today regarding the construction and reworking of their collections in a decolonized perspective.

\section{Theoretical aspects}

Interestingly, the decolonial issue has started to find interest on a theoretical level only very recently in Western museums. In 2012

7 It would be much easier to start a new collection, as some private collectors do.

8 DELISS, Clémentine. "Materiality and the Unknown, Dating, Anonymity, the Occult", Decolonising Museums, 2015, p. 34, L'Internationale Online http://www.internationaleonline.org/bookshelves/decolonising_museums, Retrieved January 2016

9 Ibid., p. 33

10 COTTER, Holland. "Making Museums Moral Again" New York Times, 17 March, 2016. http://www.nytimes. com/2016/03/17/arts/design/making-museums-moral-again. html?_r=0, Retrieved March 2016. The use of the adverb "again" implies that museums have been moral once. This questionable statement could be the subject of a whole article. the Museo Nacional Centro de Arte Reina Sofia launched a research group, Península. Procesos coloniales y prácticas artísticas y curatoriales [Colonial Processes and Artistic and Curatorial Practices], to provide

“... an analysis of the role of the Iberian Peninsula in colonial processes, the visibility of representations and narrations from diverse past and present institutional spheres, in addition to the responses of artists, curators and researchers regarding some of the problems that stem from these narrations." 11

In Spain still, a seminar curated by Paul Preciado and explicitly entitled "Decolonising the Museum" was held in November 2014 at the MACBA in Barcelona. ${ }^{12}$ It addressed colonial legacies still rooted in European museums and mindsets, as well as solutions already offered by curators to overcome these legacies. Nonetheless, this apparently recent incursion of decolonial thinking into museums was in fact preceded by a sister thinking, the postcolonial theories, which have abundantly served curatorial discourses in the West since the $1990 \mathrm{~s}^{13}$ and are to be found in art institutions under various forms that refer more or less explicitly to them. They can be located in acquisition politics through the adoption of a geopolitical revisionism, in the rewriting of new scenarios for the displays of their collection (by adopting a non-Eurocentric point of view), through the search for more horizontality in their relationships/partnerships with non-Western institutions and individualities

11 See Museo Nacional Centro de Arte Reina Sofia. Península. Procesos coloniales y prácticas artísticas y curatoriales. http://www.museoreinasofia.es/pedagogias/centro-de-estudios/investigacion/peninsula, Retrieved July 2016 12 See proceedings published on L'Internationale Online. http://www.internationaleonline.org/bookshelves/decolonising_museums (retrieved in January 2016).

13 See ALLAIN BONILLA, Marie-laure. Visualiser la théorie. Usages des théories postcoloniales dans les pratiques curatoriales de l'art contemporain depuis les années 1980. Ph.D. dissertation (art history), Rennes 2 University, 2014. 
or in their statements with the use of rhetoric borrowed from postcolonial thinkers, Édouard Glissant being the main one so far. ${ }^{14}$

The role and impact of postcolonial theories on art institutions were nonetheless reassessed at the turn of the century, which can explain this recent switch to decolonial thinking that can appear as a more effective and radical tool than postcolonial theories - the very prefix "de" implies an action whereas the prefix "post" suggests only a state, a condition. In 2000 Woolloomooloo's Artspace Visual Art Centre and The University of New South Wales organized a conference entitled "Postcolonial + Art: Where Now?" during which there was an examination of what postcolonial theories still have to provide to Australian visual arts and how postcolonial revisions of (art) history have affected (or not) mainstream institutions. ${ }^{15}$ On the other side of the planet, in Great Britain, artist and theoretician Rasheed Araeen, one of the most active supporters and diffusers of these theories through the journal Third Text, made a radical stand in an article published in spring 2000. ${ }^{16}$ According to him, the use of postcolonial theories would strengthen the dominant assumptions that they are supposed to question at the cost of the artists who would find themselves prisoners of their prescriptions. Apart from Homi Bhabha's theory of hybridity, that would be "bogus"17 because it would be ahistorical and would help promote "postcolonial exotica," 18 it is less the "cultural postcolonial theory" [sic] in itself than the "ambivalent and uncritical attitude of these postcolonial intellectuals towards

14 For more detail, see our previous article published on the topic: ALLAIN BONILLA, Marie-laure: Some Sketches for a Hypothetical Postcolonial Theories for Museums Handbook." Qalqalah. No 1, 2015, p. 51-63. Available online: http://www. kadist.org/en/programs/all/2115

15 See published proceedings: GREEN, Charles (Ed.). Postcolonial + Art: Where Now? Woolloomooloo: Artspace Visual Arts Centre, 2001.

16 ARAEEN, Rasheed. "A New Beginning. Beyond Postcolonial Cultural Theory and Identity Politics.” Third Text. $\mathrm{n}^{\circ} 50$, Spring 2000, p. 3-20

17 Ibid., p. 8.

18 Ibid., p. 12.

19 Ibid., p. 11 art institutions and their multicultural projects" ${ }^{19}$ that Araeen challenged. He reproached Edward Said for his lack of commitment to the art discourse and for leaving his idea of exile universalized and seized by the institution.

As for Stuart Hall, he condemned his insistence on perceiving the cultural journey of the artist as an essential content of the artwork, which would then be used to enhance otherness in the ideological context of multicultural politics (a cataloguing operation coined by Sarat Maharaj as "multicultural managerialism") ${ }^{20}$. Araeen sees their presence within art institutions as only a way for the latter to legitimize their neoliberal program. Unlike the Australians who endeavored to reassess the theoreticians less than the way their theories are absorbed by mainstream art institutions, Araeen concentrated almost exclusively on the role played by some of these theoreticians (Said, Bhabha, Spivak and Hall). He pursued his gripes in 2001, then in 2004, rebuking them (mostly Hall) for forging theories (of cultural difference and ethnicity), which brought about the British Black arts movement's downfall. ${ }^{21}$

If the tone and content of Araeen's criticisms are depreciatory and seem to be harsh and unfair, they should however be seen as "symptomatic of a growing unease with the contradictions in contemporary society." 22 These contradictions reside for instance in the gap between the formulation of radical theories and their effective practical applications within institutional politics. To blame theoreticians for a misuse of their theories is a fantasy of considering theoreticians as "gatekeepers

20 Sarat Maharaj quoted in HALL, Stuart, MAHARAJ, Sarat. "Modernity and Difference. A Conversation between Stuart Hall and Sarat Maharaj”, Stuart Hall and Sarat Maharaj: Modernity and Difference, (Campbell, Sarah, TAWADROS, Gilane eds) London: Iniva, 2001, p. 46.

21 See: ARAEEN, Rasheed. "Re-Thinking History and Some Other Things.” Third Text. No 54, Spring 2001, pp. 93-100; Araeen, Rasheed. "The Success and the Failure of the Black Arts Movement," Third Text. vol. 18, $\mathrm{n}^{\circ}$ 2, 2004, p. 135-152.

22 PAPASTERGIADIS, Nikos. "Cultural Identity and Its Boredom. Transculturalism and its Ecstasy”, Complex Entanglements: Art, Globalisation and Cultural Difference, (PAPASTERGIADIS, Nikos ed.), London: Rivers Oram Press, 2003, p. 162. 
of contemporary culture." ${ }^{23}$ But in reality, behind this fantasy hides a central question: what do we expect from theory and from the theoreticians? This question is fundamental to acknowledging that we cannot rely entirely on theory to build new methodologies and/or new ways of practice. Theory is a tool that can be used to justify certain choices and orientations, but it is not by any means self-sufficient. How to make theories efficient within the framework of museums? How to transpose theories into practice? A group of scholars, artists and art activists gathered under the banner of the Transnational Decolonial Institute (TDI) "critically engages the Western tradition of 'art' (which etymologically means 'skill') and uncouples art/skill from the modern belief that aesthetics could be only understood in the Kantian frame of the beautiful and the sublime, and its postmodern and altermodern updates." 24 The group co-signed a "Decolonial Aesthetics Manifesto" in 2011 and since then has been working toward a "cure to the colonial wound," ${ }^{25}$ which would result from communal work and engagement. However, despite the diversity of a few events (primarily international conferences), the activities of the TDI are not much deployed and have trouble entering art institutions and shaking them.

Finding a cure for the colonial wound is a difficult task as Sarat Maharaj underlined it. He identified a postcolonial pharmakon, at once 'poison and remedy,' to cure binarisms, and a postcolonial panacea, which would be a strategy of inversion of power relationships. ${ }^{26}$ But pharmakon and panacea are in conflict. Indeed, by overthrowing power relationships, the panacea recreates a binary system that the pharmakon then tries to treat, creating an infinite vicious circle. It was demonstrated by the curators of the Third Guangzhou Triennial in 2008

23 Ibid., p. 164.

24 See Transnational Decolonial Institute. https://transnationaldecolonialinstitute.wordpress.com/about-2/, Retrieved July 2016

25 Ibid. (a team of which Maharaj was a member) which, by attempting to overthrow postcolonial power relationships, was in the end pushed into counterproductive binarisms: Asia vs. the West, postcolonialism vs. "post-postcolonialism.” If theory should be treated cautiously insofar as it can either be distorted or increase a failure, therefore, how can an art collection concretely be decolonized? Where to begin? What are the concrete issues that the institutions are facing?

\section{Practical aspects}

To adopt a decolonized approach of the collection, which means a decentralized and non-Eurocentric point of view, is not without pitfalls. In the field of acquisition policies, programs are being set up with a mind to reach the widest scope of action, geographically speaking, in order to be as inclusive as possible. Departments devoted to non-Western areas, to which a curator from the dedicated region is usually assigned, are created to develop research comprising market investigation. Interestingly, Tate Modern's director Chris Dercon legitimized the fact of having started to buy art in geographic areas where the Western art market had not yet arrived (such as the Middle East and Southeast Asia), as a consequence of the disproportion between the museum budget and the increase in market prices. ${ }^{27}$ Dercon was not dishonest with this statement, but he failed to address the issue of Tate's position. For a European museum, collecting art from almost all over the world could be interpreted as a colonialist attitude of plundering other cultures to enrich its own. In the era of globalization, museums are caught in a paradox: on the one hand, the need to make their functions and policies evolve

26 MAHARAJ, Sarat. "Sublimated with Mineral Fury: prelim notes on sounding Pandemonium Asia", Farewell to Post-Colonialism, The Third Guangzhou Triennial, Guangzhou: Guandong Museum of Art catalog exhibition, Time Museum, 2008, p. 53.

27 Chris Dercon speaking at the international conference Les Clefs d'une passion held at the Fondation Louis Vuitton, Paris, 12 and 13 June, 2015. 
towards a geopolitical revisionism informed by postcolonial and decolonial perspectives; on the other, the risk of imposing a new geo-aesthetical expression of the Western model and perpetuating a colonial cultural domination. ${ }^{28}$ For instance, in a few decades we will have no protection at all from issues of restitutions regarding modern and contemporary artworks if attention is not paid to the way non-Western artworks are currently acquired by Western museums. ${ }^{29}$ Tate Modern attempts to resolve part of the problem by organizing international curatorial exchanges and partnerships with local organizations in Kabul, Lagos or Amman. ${ }^{30}$

International exchanges and partnerships with banks are also the solution found by the Guggenheim to implement its Guggenheim UBS MAP Global Art Initiative (2012-2017), which fosters cross-cultural interactions and exchanges between artists, curators and audiences, via travelling exhibitions,

28 See BARRIENDOS RODRÍGUEZ, Joaquín. "Geopolitics of Global Art. The Reinvention of Latin America as a Geo-Aesthetic Region”, The Global Art World. Audiences, Market and Museums, (BELTING, Hans, BUDDENSIEG, Andrea eds.), Ostfildern: Hatje Cantz, 2009, p. 98-116.

29 That is some of the acquisition logic followed by some collectors of contemporary African art such as Puma's former CEO, the German Jochen Zeitz, who has been collecting contemporary African art for about twenty years with a mind to presenting it in a dedicated museum built on the continent in order to make it accessible to an audience directly concerned. The Zeitz Museum of Contemporary Art Africa (Zeitz MOCAA) will open in 2017 in Cape Town. It will not be the first private museum of contemporary art in Cape Town. Last year, collector Piet Viljoen inaugurated the New Church, which hosts his collection of art from South Africa. Nonetheless, Zeitz's collection oversteps the borders of South Africa and is much larger. For his part, Congolese businessman Sindika Dokolo, married to the daughter of Angolan President Isabel do Santos, owns no fewer than 5,000 artworks. Pending the opening of his own venue to host his collection in Luanda, Dokolo showed it last year in Porto (Portugal) where he might establish his European base. He also fights for the repatriation of African art stolen during the Angolan civil war or the colonial period.

30 Different programs have been established such as the Unilever Series: turbinegeneration which involves schools from the U.K. and all over the world to work with Tate's collection, or the Level 2 Exchange Series which works with local art structures abroad and helps create exhibitions. educational programs, online activities and collection-building. ${ }^{31}$ This project focuses on three large regions to which art experts from those regions were appointed: June Yap for South and Southeast Asia, Pablo León de la Barra for Latin America, and Sara Raza for the Middle East and North Africa. But despite a will to have a global reach, the project radically eliminates sub-Saharan countries. This eviction was legitimized as follows: "The Middle East and North Africa share a lineage that makes their consideration as an area of focus for this project more logical than with the greater continent of Africa, especially in terms of artistic developments." ${ }^{32}$ This argument, implicitly reinforced by the idea that Arabic culture would have reached a higher level of development than Black African cultures, is the persistence of the characterization of Africa as a "heart of darkness" 33 - a recurrent point of debate since the 1990s in many discussions of contemporary African art which try to find a way to avoid this North/South separation of

31 To date, 125 artworks in a variety of mediums have been added to the collection, bringing together 67 artists from the selected areas. See the Guggenheim website for more information: https://www.guggenheim.org/MAP Retrieved July 2016

32 Extract of the statement from the director of media and public relations, Betsy Ennis, as a response given to the South African online Journal ArtThrob asking why the sub-Saharan region of Africa was left out of the Guggenheim UBS Map Global Art Initiative. The rest of the statement read as follow: "Societies in Northern Africa pride themselves for their historical links to Arabic culture and language dating to the conquest of the region by Arab Muslims in the 7 th and 8th centuries. The Middle East and North Africa have also shared the fate of suffering Western colonial rule, mainly French and British, following a postcolonial experience where Egypt took the lead in advocating national rhetoric that based itself on an Arab cultural revivalism in the early 20 th century. There are shared cultural commonalities that continue to tie the North African states to their counterparts in the Middle East. Arabic language, and primarily its script, play a leading role in disseminating political and cultural coherence. Language and script were particularly important tools for artists in the mid-century who utilized script to create a unique abstract modern visual discourse. Contemporary artists continue to explore these shared histories and legacies." Published online 18 April, 2012, by BLACKMAN M., "Sub-Saharan Africa out in the Cold", Artthrob. http://www.artthrob.co.za/News/ Sub-Saharan-Africa-out-in-the-Cold-by-M-Blackman-on-18April.aspx\# Retrieved May 2012. No longer available). 33 See for example Olu Oguibe argument in "In the Heart of Darkness", Third Text. N ${ }^{\circ} 23,1993$, p. 3-8. 
the African continent. Apart from the cultural justification, the eviction of the southern part of the African continent by the Guggenheim UBS MAP Global Art Initiative could also be interpreted through the economical prism of prospective partnerships, which seems to be more appealing (promising?) in the Middle East than in Senegal or Democratic Republic of Congo in the eyes of UBS. Furthermore, the presence of UBS, the infamous Swiss bank involved in financial scandal in 2008, as the main partner of the Guggenheim project irremediably links this Global Art Initiative to capitalism and dubious financial practices (it is even disconcerting that the bank name appears in the title of the project, in a way thus colouring the whole project with this financial aspect). As Reesa Greenberg wrote,

\section{"The term private money resonates} because in many spheres of the art world, particularly after the financial crises of 2008, private money is perceived as negative, even malevolent, in part because of the ever-inflating art market, and in part because the excessive wealth of the $1 \%$ has once again transformed the art world into a favored playing field for the super-rich, where artworks function as über-luxury goods." ${ }^{34}$

If involvement in this philanthropic project would be one of the ways for UBS to make amends publicly, it seems however, under the pretext of promoting art, to be a niche where they can develop other financial placements and partnerships and expand their activities

34 GREENBERG, Reesa. "Activist-Patron-Curators and North American Museums”, Curating and Politics. Beyond the Curator: Initial Reflections, (BALE AMUNDSEN Heidi, MØRLAND Gerd Elise eds.), Ostfildern: Hatje Cantz, 2015, p. 53.

35 BARRIENDOS RODRÍGUEZ, Joaquín. loc. cit., p. 110. The expression "coloniality of power" was coined by sociologist and political specialist Aníbal Quijano. See: "Colonialidad y modernidad/racionalidad." Perú Indigena, vol. 13, n 29 , 1992, p. 11-21. Translated into English in Modernities and Globalizations. European and Latin American Experiences and Perspectives, (THERBORN, Göran ed.), Stockholm: Forksningsrådnämnden, 1999, p. 41-51.

more globally. According to Joaquín Barriendos Rodríguez, the concept of global art, supposedly synonymous with openness and free circulation, is nonetheless the expression of the coloniality of power. ${ }^{35}$ Therefore, the way museums do acquire artworks from all over the world and the financial partnerships they contract to complete this task must be interrogated. Inasmuch as museums drastically lack public funding, they must turn to the private sector to get their projects funded. But at what price? In a recent article, art critic Holland Cotter pointed out that:

"Some museums [the MET, the Guggenheim] were urged to stop taking money from ethically dubious corporate or personal sources, including board members who deny that climate change is underway. Others were called out for condoning, if not actively supporting, inhumane labor practices, like those imposed on migrant workers building new Guggenheim and Louvre franchises in Abu Dhabi." 36

Knowing the role played by colonialism in the genesis of capitalism, solutions have to be found in order to decolonize funding and to aim for more horizontality in South/North exchanges. In October 2011, a Nigerian bank, Guaranty Trust Bank, entered into a partnership with Tate Modern, which has created and funded a curatorial post, a comprehensive acquisitions remit and related programming dedicated entirely to increasing the presence of contemporary African art in the London museum. Like Guggenheim/UBS, the Tate

36 COTTER, Holland. "Making Museums Moral Again." New York Times. 17 March, 2016: http://www.nytimes. com/2016/03/17/arts/design/making-museums-moral-again. html?_r=0 Retrieved in March 2016 
Modern/Guaranty Trust Bank partnership has been imagined on a model of institutional networking and "knowledge exchange." Significant in the case of the Tate Modern was the appointment in 2011 of a new curator whose position was entitled "Curator International Art" and not "Curator for contemporary African art." Elvira Dyangani Ose is working not only to bring African art into Tate's galleries in London, but also to broaden Tate's international reach in Africa, as with, for instance, the Across the board program, a twoyear interdisciplinary project that took place in London, Accra, Douala and Lagos. ${ }^{37}$ This partnership between a Nigerian bank and a British museum is not just the establishment of a temporary program grafted to the museum but a program aimed at modifying the institution from the inside.

Collections “ $[\ldots]$ are both about our failings and about our successes. They signify relations between things and ideas, between the inheritance of meaning and its erasure over time." ${ }^{38}$ Therefore, beyond finding ethical funding in order not to reproduce the coloniality of power, museums have to define the terms of their collection and for this probably to look at their shortcomings and make an introspective study to see how to address lacks. For instance, the Stedelijk Museum and the Centre Pompidou each recently organized an exhibition of their collection addressing the issues of these latter (more than 100,000 artworks for the Parisian museum and 90,000 for the Amsterdam museum). At the Stedelijk Museum, the question was to know whether the museum "reflect[ed] the geopolitical reality of the world?" 39 After having gone through the numbers of artworks from Africa, Latin
America, Asia and the Middle East in the collection, the assessment was that the representation of "art from areas outside Europe (particularly Western Europe) and North America (i.e., the United States) is marginal. That is, as statisticians would say, insignificant. In itself, this is nothing new." ${ }^{40}$ In his essay, Jelle Bouwhis, the curator responsible for the exhibition How Far How Near-The World in the Stedelijk (September 19, 2014 - February $1,2015)$, returned very precisely to the history of the exhibitions held at the Stedelijk since the 1930s which displayed non-Western art. ${ }^{41}$ From objects from Papua New-Guinea and Africa, exhibited along with artworks from European modern artists, to African photography through art from South America, the history of Stedelijk exhibitions unveils the influence of "Soft Power" on the museum, which is "the continuous ratification - through art, among other thingsof an argument until people actually believe it and lose sight of other possibilities including the corresponding expertise and networks." ${ }^{42}$ Within this framework, Soft Power has to be understood as the possibility for modern art to "represent an ultimate notion of freedom and cultivate forms of (geographically motivated) exclusion." ${ }^{* 3}$ It explains why exhibitions of South American artists or South African artists could have been organized at the Stedelijk but without receiving "a follow-up, simply because the presented works were difficult to slot into the paradigm of modern art." ${ }^{44}$ At the turn of the 21 st century, the Stedelijk opted for a different strategy, establishing long-term programs such as Project 1975: Contemporary Art and the Postcolonial Unconscious or Global Collaborations that were meant to develop partnerships with
37 A booklet can be downloaded on the Tate Modern's website: http://www.tate.org.uk/download/file/fid/21395 Retrieved July 2016

38 DELISS, Clémentine. "Materiality and the Unknown, Dating, Anonymity, the Occult.”, Decolonising Museums. 2015, p. 24 In L'Internationale Online: http://www.internationaleonline.org/bookshelves/decolonising_museums, Retrieved in January 2016

39 BOUWHIS, Jelle. "How Far How Near-The World in the Stedelijk", In How Far How Near-The World in the Stedelijk, catalog exhibition, Amsterdam: Stedelijk Museum, 2014, p. 1.
40 Ibid., p. 2.

41 See Ibid., pp. 1-16.

42 Ibid., p. 9.

43 Ibid., p. 15

44 Ibid., p. 12 
art institutions in Africa, the Middle East and South Asia through exhibitions, residencies, exchanges and collaborations, etc. Furthermore, the Stedelijk started to purchase the artworks produced (or selected) for the exhibitions held during those programs, building piece by piece a collection reflecting more accurately the shift of the museum towards more inclusivity of non-Western artists. How Far How Near exhibited some of these artworks, such as those of Meschac Gaba, Godfried Donkor, Abdoulaye Konaté or Billie Zangewa, showing a strong leaning toward artists from the African continent.

At the Centre Pompidou, the story is quite different. Une histoire: art, architecture et design, des années 80 à aujourd'hui was a collection display curated by Christine Macel and held at almost the same moment as the one in Amsterdam (July 2, 2014 - January 11, 2016). It then traveled to the Haus der Kunst in Munich under the title A History: Contemporary Art from the Centre Pompidou (March 25 - September 4, 2016). With more than 400 artworks on display, the aim of this exhibition was to show the extent of the collection rather than to reassess its shortcomings and lacks. Unlike the Stedelijk exhibition that was a critical introspection, the curator's essay shows that the aim was to inscribe the Centre Pompidou's approach into the classical discourse on the globalization of the art world (starting with 1989, the biennials phenomenon, etc.) and not to reassess the pitfalls of the collection regarding this history. ${ }^{45}$ If Macel recognized that "because it has become nearly impossible to keep track of the entire worldwide development of art, a targeted selection was made rather than the goal of totality

45 See the English online version: MACEL, Christine. "A History." Haus der Kunst: http://issuu. com/haus_der_kunst/docs/160418.hdk.essay.christine_ macel $/ 5$ ? $=4227978 / 35159290$, Retrieved July 2016

46 MACEL, Christine. Op. Cit., p. 4.

47 To pick just two examples: Chéri Samba is the only painter from the sub-Saharan part of the African continent to be represented in the collection of the Centre Pompidou, and only five photographers from this area are represented as well (Zanele Muholi, David Goldblatt, Guy Tillim, Malick Sidibé and Samuel Fosso). pursued." ${ }^{46}$ The non-Western areas, particularly the sub-Saharan part of the African continent, are nonetheless underrepresented in the collection. ${ }^{47}$ It is thus surprising to have chosen a photograph by Samuel Fosso ( $\mathrm{La}$ Femme américaine libérée des années 70, 1997, acquired in 2004) to illustrate the press release sent by e-flux as well as the announcement on the Haus der Kunst website. But what Macel asks is how to address the concept of global art in terms of a collection and how to resolve the problem of the recontextualization of an artwork. Does any so-called good, self-respecting museum need to own some "basic standards" of a (global) art history in its collection? To think in reverse, in China for instance, newly founded museums are compulsively acquiring Impressionist canvases. This is less a will to include the European avant-garde in the discourse of Chinese art history, than it is the strong use-value of these artworks that is sought in order to be appealing for tourism, following the "impartial economic logic [saying that] the 'success' of museums is determined by the number of visitors they attract." ${ }^{48}$ Beyond the stakes of the market, what is the epistemological interest in owning these masterpieces? The question can be applied to any museums in the world collecting art from another part of the world, which is seen as marketable or exotically stimulating (pick one). It seems urgent to rethink the role and the mission of art museums before the globalization phenomenon, after the modern one, creates homogenized spaces and narrations where we would see almost the same kind of artworks and discourses whether we are in Rio, Houston, Seoul or Abu Dhabi.

48 KOOIMAN, Mirjam. "The Dutch VOC Mentality." In L'Internationale Online (Ed.). Decolonising Museums. 2015, p. 45. http://www.internationaleonline.org/bookshelves/decolonising_museums, Retrieved January 2016 


\section{Conclusion}

For Western museums of modern and contemporary art, the shift toward a decolonial approach of their acquisition practices was clearly triggered not by the Independences but much later by the globalization phenomenon which accentuated the imbalances and therefore called for non-Eurocentric policies. The different examples discussed in this article show that the idea of decolonizing Western museums' art collections, implying at least two aspects, the theoretical and the practical, is a very complex issue which is worth thinking about. However, this decolonial challenge cannot be limited to acquisition policies and should be considered in various museums' sectors, whether it is acquisition policies turned toward non-Western artists and areas, collection displays with new narratives or the programming of temporary exhibitions of artists previously marginalized, or museums' politics at large, such as the recruitment of non-Western/non-White people or education programs specifically oriented to the deconstruction of dominant discourses. The question of how to succeed or to conceive a decolonization of museums (collection) cannot be reduced to only the theoretical search of a remedy that could be applied to any museums_-each museum has its own history and therefore should look for its own recipe-nor can it rely only on the purchase of artworks supposed to rectify the narratives. The battle will probably not be won until museums become spaces of "knowledge-without-power," ${ }^{99}$ taking full responsibility for their role in the construction of influential narratives that are shaping the history of art, and more broadly the history of our world, in our collective memories. 


\section{Est-il possible de décoloniser l'art moderne et contemporain des musées occidentaux?}

«Est-il possible de décoloniser les musées des collections d'art contemporain et moderne? "Cette question apparemment naïve, est fondée à partir d'observations de transformations tangibles au sein de paradigmes propres au champ muséal. Depuis le début du $21^{\text {ème }}$ siècle, les musées d'art contemporain et moderne occidentaux n'ont eu en réalité, d'autre choix que de reconfigurer leur programmation et la composition de leurs collections à la lumière de la globalisation de l'art contemporain, des politiques de différence culturelle, du besoin de remodeler l'histoire de l'art moderne, et d'inclure, tel que réclamé par les théories postcoloniales, la voix des "Autres ". L'un des principaux défis postcoloniaux et décolonisateurs des musées d'art moderne est probablement de " provincialiser l'Europe ", dans la mesure où la modernité est intrinsèquement liée à l'impérialisme européen et coïncide avec l'eurocentrisme. Le but de «provincialisation de l'Europe " réside moins dans le rejet de la modernité que dans l'intégration de l'ambivalence dans ses récits, et de l'actualiser en incorporant ce qui en a été exclu. Ce défi se décline en de nombreuses applications, prenant la forme de programmation d'expositions temporaires, de politiques d'acquisition, d'expositions de collections ou de programmation de conférences.

Dans la sphère des politiques d'acquisitions muséales, nous assistons à l'élaboration de programmes qui cherchent à atteindre l'élargissement géographique de leur champ d'action. Fait intéressant, le directeur de London Tate Modern, Chris Dercon, a légitimé le fait d'avoir commencé à acquérir l'art de zones géographiques encore inexplorées où le marché de l'art traditionnel (Moyen-Orient et Asie du Sud-Est) et la disparité entre le budget des institutions muséales et les prix du marché, est toujours plus élevée ${ }^{1}$. Sans être complètement malhonnête, Dercon a évité d'aborder l'argument de la position qu'occupe la Tate Modern, soit celle d'un musée occidental réunissant l'art de toutes les parties du monde, une position qui en fait reproduirait l'attitude colonialiste de dérober d'autres cultures pour s'enrichir soi-même. Les musées sont en effet pris dans un paradoxe: ils doivent d'une part, composer avec la nécessité de faire évoluer leurs fonctions et leurs politiques vers un révisionnisme géopolitique éclairé par des perspectives postcoloniales et décoloniales. Ils risquent d'autre part, d'imposer une nouvelle expression géo-esthétique occidentale et perpétuer une domination culturelle coloniale.

De 2012 à 2017, l'UBS Guggenheim MAP Global Art Initiative a favorisé l'interaction interculturelle entre les artistes, les conservateurs et les publics via des programmes éducatifs, des activités en ligne et la constitution de collections. L'organisme s'est concentré dans les régions de l'Asie du Sud et du Sud-Est, de l'Amérique latine, du Moyen-Orient

1 Chris DERCON, allocution livrée lors de la conférence internationale Les Clefs d'une passion à la Fondation Louis Vuitton, Paris, 12-13 Juin 2015. 
et de l'Afrique du Nord - et a radicalement exclu les pays subsahariens. Cette exclusion est légitimée par le fait que : "Le Moyen-Orient et l'Afrique du Nord partagent une lignée qui fait de leur prise en considération un axe de réflexion plus pertinent, notamment en termes de développement artistique, qu'avec tout l'ensemble du continent africain"2. Cet argument, renforcé par l'idée que la culture arabe serait plus évoluée que les cultures négro-africaines, témoigne de la persistance d'un "cour des ténèbres"3, un point de débat récurrent dans de nombreux débats sur l'art africain qui cherchent à éviter la séparation septentrionale et méridionale du continent. Cet exemple montre que l'idée de décoloniser les politiques d'acquisition n'est pas une idée à la mode mais qu'elle constitue un enjeu fondamental pour les musées d'art du XXI siècle, et qui mérite d'être approfondi.

Cet article est élaboré à partir de cet aspect crucial et explore à partir d'exemples précis, les questions suivantes: Comment est-il possible de décoloniser une collection? S'agit-il d'un objectif utopique, irréalisable? Qu'est-ce qui est impliqué par pratique décoloniale? Quelles sont concrètement les prospectives pour ces institutions et quels sont les approches disponibles? Les théories décoloniales et postcoloniales sont-elles des réponses efficaces pour résoudre les problèmes éthiques? Comment ces théories peuvent-elles devenir opératoires au sein des musées? Comment transposer ces concepts dans la pratique? S'agit-il d'un défi qui ne concerne que les pays occidentaux ou concerne-t-il aussi les pays africains ou sud-américains? Que signifie réévaluer de l'art de façon décolonisée? Comment est construite et activée la polyphonie d'une collection?

2 Extrait de la déclaration de la directrice des relations publiques et media, Betsy Ennis en guise de réponse à la publication en ligne sud-africaine ArtThrob au sujet de l'exclusion de la région subsaharienne de l'Afrique par le Guggenheim UBS Map Global Art Initiative. Publiée en ligne le 18 avril 2012 par M. Blackman, < http://www.artthrob.co.za/News/ Sub-Saharan-Africa-out-in-the-Cold-by-M-Blackman-on-18April.aspx\#>

3 Voir l'argument de Olu Oguibe dans "In the Heart of

Darkness", Third Text, 23, 1993, p. 3-8. 